\title{
Undergraduate Pre-service EFL Teachers' Conceptions of Research: A Quantitative Analysis
}

\author{
Concepciones de investigación \\ de los futuros profesores de inglés
}

\author{
María del Rosario Reyes-Cruz ${ }^{1}$ \\ Lorgia Isamar Rueda de León-Barbosa² \\ Griselda Murrieta-Loyo ${ }^{3}$
}

\begin{abstract}
Citation/ Para citar este Artículo: Reyes-Cruz. M., Rueda de León-Barbosa, L., \& Murrieta-Loyo. G. (2017). Undergraduate Pre-service EFL Teachers' Conceptions of Research: A Quantitative Analysis. Colomb. Appl. Linguist. J., 19(1), pp. 67-83.

Received: 05-May-2016 / Accepted: 18-Aug-2016

DOI: http://dx.doi.org/10.14483/calj.v19n1.10534

Abstract

This study explores the conceptions of research of undergraduate pre-service teachers from an English language major at a public Mexican university from a pragmatist definition of research. A survey design was used. The informants were 108 pre-service EFL teachers of the second, sixth, and tenth semesters of the major. The conceptions of research showed similar percentages among the pre-service teachers in those semesters. Only a slight variation was found in the factor "misconceptions about research." The factor "research is about problem solving" was the only one that showed a significant but weak correlation with the semester in which undergraduate pre-service EFL teachers were. Slight differences were also found between age range and conceptions of research. The overall lack of differences among the research conceptions of these undergraduate pre-service EFL teachers is opposed to the findings of previous studies. This can be explained by the fact that those studies were done in different contexts and with graduate students from disciplines different from foreign language teaching. It is suggested that students' misconceptions should be corrected and research activities should be promoted during their studies.
\end{abstract}

Keywords: conceptions, English, research, undergraduate teachers

\section{Resumen}

Este estudio explora, desde una perspectiva pragmatista de la investigación, las concepciones sobre la investigación de estudiantes para profesores de inglés de una universidad pública mexicana. Se utilizó un diseño por encuesta. Los sujetos fueron 108 estudiantes pertenecientes a segundo, sexto y décimo semestres. Las concepciones sobre la investigación mostraron porcentajes similares entre los estudiantes de los diversos semestres. Sin embargo, se encontraron pequeñas diferencias en el factor denominado "concepción equivocada." Únicamente el factor "la investigación se trata de solucionar un problema" mostró una correlación significativa pero débil con el semestre en el que se encontraban los estudiantes. De igual manera, se hallaron pequeñas diferencias entre la edad de los estudiantes y sus concepciones sobre la investigación. La falta de diferencias entre los estudiantes según los diversos semestres es opuesta a la tendencia de los estudios previos. Lo anterior podría deberse a diferencias contextuales

\footnotetext{
1 University of Quintana Roo, Quintana Roo, México. rosreyescruz@hotmail.com

2 Colegio de las Américas. lorgy_8@hotmail.com

3 University of Quintana Roo.grises@uqroo.edu.mx
} 
y disciplinarias. Se sugiere instrumentar acciones para corregir las concepciones equivocadas de los estudiantes y desarrollar la habilidad de investigación a través del currículo.

Palabras clave: concepciones, estudiantes de licenciatura, investigación, inglés

\section{Introduction}

Conceptions of research is a recent subject for exploration; consequently, there is a paucity of published studies investigating conceptions of research in different areas. Questions and possible hypotheses that have been raised about conceptions of research have come from different fields such as psychology (Love, Bahner, Jones, E Nilsson, 2007), education (Beycioglu, Ozer, \& Teyyar, 2010), nursing, and science (Halabi $E$ Hamdan-Mansour, 2010). The majority of these contributions have dealt with teachers' conceptions of research (Allison $\mathcal{E}$ Carey, 2007; Kiley E Mullins, 2007; Lucas, Healey, Jenkins, E Short, 2008; Moore, 2011), yet it would seem then that students' conceptions are set aside. In the field of applied linguistics, the research investigating this subject is still less frequent. The pioneering work of Borg (2008, 2009, 2013) also addresses language teachers' conceptions of research.

There is a limited number of studies about students' conceptions of research among different groups such as post-docs (Pitcher $\varepsilon$ Åkerlind, 2009), doctoral students (Pitcher, 2011) and master's degree students (Meyer, Shanahan, E Laugksch, 2005). These studies used various instruments and methods such as participantobservation, surveys, interviews, questionnaires, and others in order to explore participants' conceptions of research; however, none of them have dealt with undergraduate pre-service EFL teachers.

Nowadays, research is internationally conceived as a constitutive part of EFL teacher training. Edwards (2005) asserts that language teachers who do research are more confident in approaching professional challenges in a principled way. However, in Mexico, it seems we are lagging behind in this tendency since research in this area is still emergent
(Ramírez, 2013). The number of English language teachers at the university level who do research is low. Consequently, the majority of undergraduate preservice EFL teachers, according to our experience, has little exposure to research and are not interested in doing it.

The way students perceive research has a strong influence on the research approach they engage in as well as in the research process itself (Kiley $\&$ Mullins, 2007). Since the literature has shown that doing research produces a positive influence on teachers' performance (Atay, 2006) and students' learning (Bell, Cordingley, Isham, \& Davis, 2010), it seems important to diagnose undergraduate pre-service EFL teachers' conceptions of research in order to provide suggestions for further teacher preparation.

The overall goal of this study was to identify the conceptions or misconceptions of research held by pre-service EFL teachers of the 2nd, 6th and 10th semesters of the English language major at Southeastern University (a pseudonym) in México. An additional goal was to provide a comprehensive explanation of these undergraduate pre-service EFL teachers' conceptions of research by identifying differences in two variables: 1) across different semesters and 2) according to their age. In order to investigate these pre-service EFL teachers' conceptions of research, the following question was addressed:

RQ1: What kind of conceptions of research predominates among undergraduate pre-service EFL teachers?

The following hypotheses were also proposed:

$\mathrm{H} 1$ : There is a correlation between students' academic year and conceptions of research.

$\mathrm{H} 2$ : There is a difference in conceptions of research by age group.

The scarcity of empirical research on students' conceptions of research (Brew, 2001), particularly in undergraduate pre-service EFL teachers in the field of applied linguistics, makes this study relevant since, to the best of our knowledge, there are no published studies in México regarding this topic. Furthermore, this kind of research may serve to inform teachers and authorities of the factors that might have been 
obstructing undergraduate pre-service EFL teachers from undertaking research projects. It is a fact that many undergraduate pre-service teachers have difficulties completing research projects and their honors theses. Many factors might be responsible for those problems, such as lack of motivation, misconceptions about research, or ignorance of the importance of research in EFL.

Therefore, this study might be useful for both undergraduate pre-service teachers and teacher trainers. The results may help undergraduate preservice teachers become aware of the importance of research in their academic training, and teachers might be informed as to students' conceptions of research. This understanding could be of help to teachers since knowing students' conceptions of research might help them better approach their students' research problems. It is essential that both teachers and students have clear and similar conceptions of research since a mismatch between them might cause communication issues (Bills, 2004; Lee, 2008; Pitcher, 2011). The results of this study could help educational institutions to identify strategies to avoid or correct undergraduate preservice EFL teachers' misconceptions of research.

\section{Literature review}

Existing literature on EFL teachers' research conceptions area is emerging (Allison $\mathcal{E}$ Carey, 2007; Borg, 2008, 2009, 2013; Gao, Barkhuizen, \& Chow, 2011). However, searching both international and national database provided no study on research conceptions of pre-service EFL teachers. Therefore, the literature review we present here is limited and belongs to areas different from EFL. Nevertheless, we think these studies constitute a basis for the present research. It is important to mention that several terms have been used by different authors to explore conceptions of research. These terms include "perceptions," "beliefs," and "views." For that reason, the review of literature we present here includes studies whose definition is equivalent to the term 'conception,' even though some of them did not use this very term. In the present study, the term "conceptions of research" is used to mean what undergraduate pre-service EFL teachers think of research and understand about it (Kiley $\mathcal{E}$ Mullins, 2007; Pitcher, 2011).

Meyer, Shanahan, and Laugksch (2005) explored the dimensionality of students' conceptions of research from two complementary research perspectives, the qualitative and quantitative approaches. The group of participants was mixed, and few of them were undergraduates while the majority was graduates. The qualitative approach was used to design the Students' Conceptions of Research Inventory (SCoRI). The factor analysis of this instrument yielded six factors labelled (F1) misconceptions about research, $(\mathrm{F} 2)$ research is re-search, $(\mathrm{F} 3)$ research is an insightful process, (F4) research about problem solution, (F5) research is finding the truth, and (F6) research is gathering information. In the discussion, the researchers pointed out that their sample did not exhibit a uniform approach to conceptualizing research nor its process.

Pitcher and Åkerlind (2009) used metaphors to analyze post-doctoral researchers' conceptions of research in five Australian Universities. The participants were 19 post-doctoral researchers (PDRs) who were selected by using a nation-wide survey to represent the demographic variation (in PDRs) with the aim of capturing variations in conceptions. The researchers belonged to different fields. The analysis yielded four categories of dominant conceptions which were named on the basis of the dominant concepts: research is explorative, research is spatial, research is constructive, and research is organic. One interesting fact is that, apparently, there was no close relationship between the conceptions of research and the students' field of study, which is in agreement with the findings of Lucas, Healey, Jenkins, and Short's (2008) study of teachers.

Pitcher (2011) used metaphor analysis to study doctoral students' conceptions of research at an Australian university. Students from a variety of disciplines were asked to answer questions related to their conceptions of research via an on-line survey. As in Pitcher and Åkerlind (2009), the analysis yielded four categories labeled as "dominant metaphorical concepts" which include: a) research is explorative, b) research is constructive, c) research is spatial, and d) research is organic. 
Like Lucas et al. (2008), Pitcher (2011) did not find any differences in conceptions of research across students with different disciplinary backgrounds. Pitcher compared the categories he found with the ones provided by Meyer et al. (2005) and pointed out that they overlapped with some slight differences. Furthermore, Pitcher (2011) compared his findings with those in Pitcher and Åkerlind (2009), noting that the conceptions of research categories among post-doctoral research and doctoral students were similar, except for one, "research is organic." He asserts that this variation resulted from the seniority differences between the two groups of participants.

The literature about students' conceptions of research is extremely limited. Moreover, the studies we found were carried out with graduate students and not with undergraduate pre-service EFL teachers. Thus, this study aims at adding literature to the study of EFL undergraduate teachers' conceptions of research. Another aspect worth mentioning is that none of the studies above provides a definition of research. In this study, research is defined from a pragmatist approach as a systematic activity not associated with any particular philosophy system of reality which pursues the answer of a posed problem that occurs on a determined socio-historical and political context (Biesta $\&$ Burbules, 2004). This kind of research allows the use of different data collection methods, either quantitative or qualitative, depending on which is more suitable to achieve the objective. In this perspective, the truth is conceived inside and outside the researcher's mind and with a relational character.

\section{Methodology}

This study was conducted with a quantitative approach; specifically, a survey design was chosen (Muijs, 2004).

\section{Instrument}

We used the second version of the SCoRI, a questionnaire developed by Meyer, Shanahan, and Laugksch (2005). The questionnaire was divided into six factors which were initially labeled as (F1) misconceptions about research, (F2) research is re- search, (F3) research is an insightful process, (F4) research about problem solution, (F5) research is discovering the truth, and (F6) research is gathering information.

In the original research, the authors were not able to determine a conceptualization for the three items that loaded on factor six. In addition, the items overlapped with the remaining five factors. Therefore, the sixth factor was not taken into consideration in our research. In other words, only five factors (with a total of 33 items) together with five demographic data items constituted the instrument used for this present study. Factor 1. Misconceptions about research (8 items), Factor 2. Research is research (7 items), Factor 3. Research is an insightful process (7 items), Factor 4 . Research is finding the truth (6 items), Factor 5. Research about problem solution (5 items). Moreover, the instrument was translated into Spanish in order to ensure students' comprehension as it is their native language.

\section{Reliability Analysis}

According to Golafshani (2003), reliability is a useful measure for evaluating the consistency and accuracy of an instrument. The reliability of Cronbach's alpha was .87, which, according to DeVellis (1991), can be considered as adequate.

\section{Description of the Sample}

The participants were three groups of undergraduate pre-service EFL teachers enrolled in the English language bachelor's degree program at Southeastern University (a pseudonym). The groups were constituted as follows:

- The first group were 2nd semester pre-service teachers of the English language major. These pre-service teachers were included because in the 1st semester they took a course titled metodología de la investigación (research methods) which introduces them into the concept of research.

- The second group were 6th semester preservice teachers. These pre-service teachers were included because they too took the course Metodología de la investigación long before 
the first group did, but also because they had not yet taken the course titled seminario de titulación (research seminar), which is taught in the 9th semester.

- The third group were 10th semester pre-service teachers. These pre-service teachers had taken both courses (metodología de la investigación and seminario de titulación); therefore, they supposedly were more familiarized with the concept of research.

Age is considered as a variable in this present study. Therefore, all pre-service EFL teachers enrolled in the 2nd, 6th and 10th semesters of both shifts (morning and afternoon) were invited to participate in order to have varying ages. The other variable was the semester. The reason we included the 2nd, 6th and 10th semesters is that, as we explained above, these pre-service EFL teachers are to take two different research courses during their major. It is worth noting that both courses (research methods and research seminar) are compulsory in the English language program which aims at training teachers of English as a foreign language.

\section{Procedure}

We asked teachers for permission to conduct the survey in their classrooms, to which they agreed. We explained to the pre-service EFL teachers that the survey was anonymous and voluntary, and that the results would be used just for research purposes. They consented verbally to answer the questionnaire.

\section{Analysis of the Data}

To analyze the data, we used descriptive statistics. Cross-tabulations were necessary for establishing differences between age and conceptions, and Spearman's rho coefficient was used to find out the correlation between semesters and conceptions. We intended to carry out a census; unfortunately, not all undergraduate pre-service EFL teachers attended classes the day the questionnaire was administered. Therefore, the sample was constituted by a total of 108 participants, 45 were from second semester, 41 from sixth semester, and 22 from tenth semester. All the participants were undergraduate teachers from the
English language major studying at the Southeastern University (pseudonym) during spring term in 2015. Sixty-nine participants were women and 39 were men; 52 were in the 21 - 23 years old range, 44 were in the 18- 20 years old range, 9 were in the $24-26$ years old range and 3 were 27 years and older.

\section{Results}

We now address the questions and hypotheses in the same order we established at the beginning of this paper. RQ1: What kind of conceptions of research predominates among undergraduate pre-service EFL teachers and is there a difference among the conceptions of these pre-service EFL teachers from diverse semesters?

Frequency distribution analyses as well as measures of central tendency were carried out with all of the information of the dependent variables in order to know undergraduate pre-service EFL teachers' conceptions of research. The findings are presented individually. First, we explain the findings of second semester, then sixth semester, and finally, the ones from tenth semester.

Before the findings, the concept of each factor (a total of five in this research) is presented. Nevertheless, it is important to mention that Meyer et al. (2005) do not state a definition explicitly for each of the factors they proposed as conceptions of research; instead, they rephrase the items or give examples. Regarding the results found in the present research, the following figures show the general tendency (in percentages) of undergraduate pre-service EFL teachers' conceptions of research. The percentages were obtained by calculating the total sum of the items responses and then dividing the sum by the total number of items.

Figure 1 shows the variation on undergraduate pre-service EFL teachers' conceptions of research in Factor 1 "misconceptions." Some of the survey items of this factor are the following ones: "Good research specifically gathers data that will support the researcher's preconceived idea, research becomes true after it is published" (Meyer et al., 2005, p. 36). Sixth semester pre-service EFL teachers reached 
the highest percentage in the options "agree" and "strongly agree" which means that pre-service EFL teachers from 6th semester do have research misconceptions. In second place are pre-service EFL teachers from 2nd semester, followed by preservice EFL teachers from 10th semester.

Some items of the factor "research is re-search" are the following ones: "Research is finding out about something that is already there, an investigation to find facts left out by previous researchers" (Meyer et al., 2005, p. 36). As seen in Figure 2, there is almost no variation in Factor 2 "research is re-search," as the three semesters got similar percentages.

In the factor "research is an insightful process," research is explained as:
Providing a deeper insight and understanding of a particular topic, extending concepts, stimulating further interest or work in a particular area. (Meyer et al.,2005, p. 36)

Once more, there is almost no variation. As shown in Figure 3, the percentages of undergraduate pre-service EFL teachers' conceptions are very similar among participants in factor 3 .

Factor 4, "research is finding the truth," has the following meaning:

Research here is seen essentially in terms of the quest for truth, in terms of fundamentally finding out, uncovering, or exhuming the truth, systematically hunting for the truth about

Figure 1. Tendency on Factor "Misconceptions."

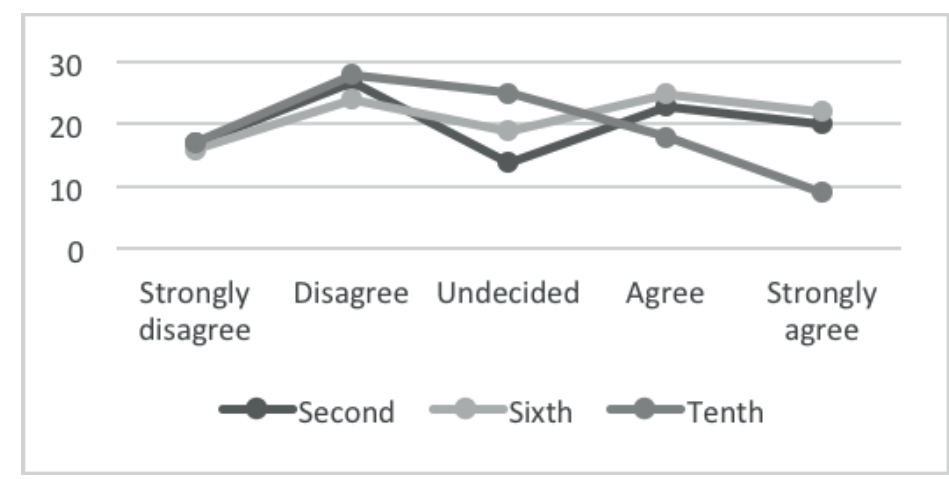

Figure 2. Tendency on Factor "Research is re-search."

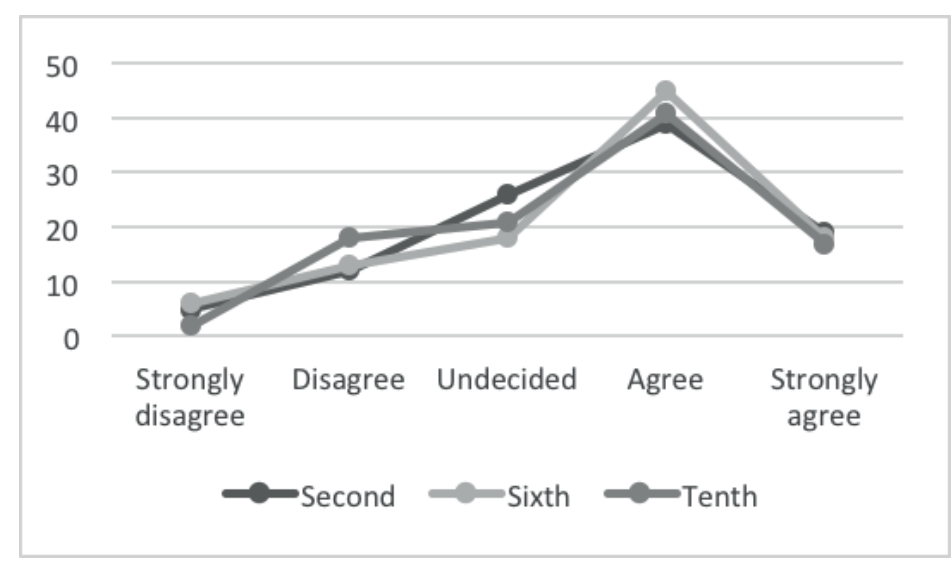


something, and as something which is done to determine the truth or validity of something. (Meyer et al., 2005, p. 35)

There is a variation in the option "agree" in factor 4 "research is finding the truth." In this factor, preservice EFL teachers from 10th semester achieved the lowest percentage. For more details, see Figure 4.

Factor 5 "research about problem solution" is described as:

Finding solutions to problems, or to stated problems, as a tool for answering questions, collecting data to solve particular problems, and as the careful and thorough study of a problem.

(Meyer et al., 2005, p. 36)

As it can be seen from Figure 5, the three semesters scored similarly on factor 5 "research about problem solution."

In general, undergraduate pre-service EFL teachers' conceptions of research showed a high variation on factor 1 (misconceptions about research): undergraduate pre-service EFL teachers in sixth semester got the highest percentage in the options "agree" and "strongly agree," whereas preservice teachers in tenth semester got the lowest percentage. By making a comparison among the five types of conceptions, it was found that the one

Figure 3. Tendency on Factor "Research is an insightful process."

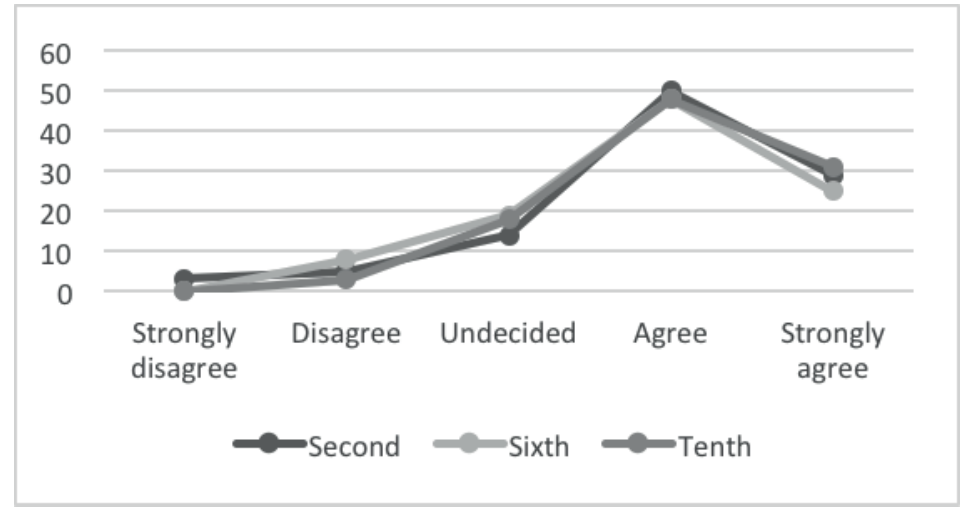

Figure 4. Tendency on Factor "Research is finding the truth."

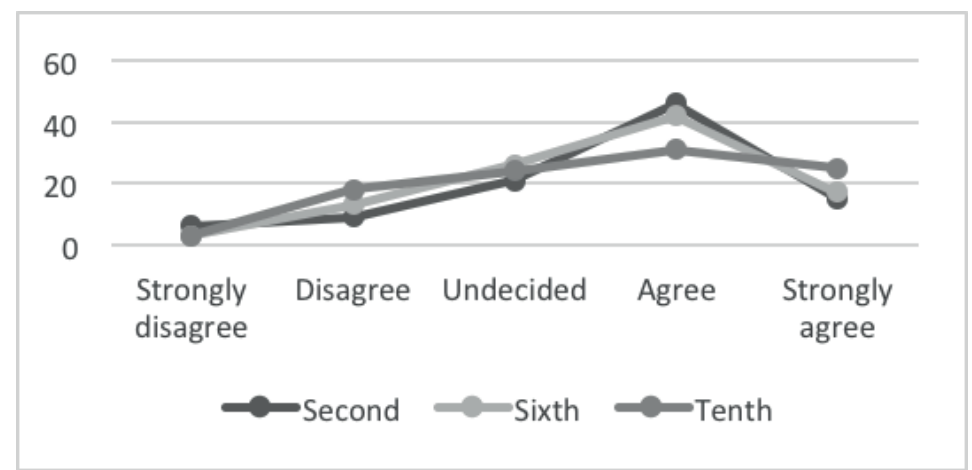


with the highest percentage was the "research is an insightful process" factor, while three out of four of the remaining conceptions got similar percentages. The lowest factor was "misconceptions" which appeared to be beneficial for pre-service teachers in relation to conceptions of research. For more details, see Figure 6.
Now we address hypothesis one: There is a correlation between students' academic year and conceptions fo research. Spearman's rho rank-order correlation coefficient was used for the correlation between semesters and conceptions. Only one out of five factors showed a significant correlation with the variable "seniority": the fifth factor "research is

Figure 5. Tendency on Factor "Research about problem solution."

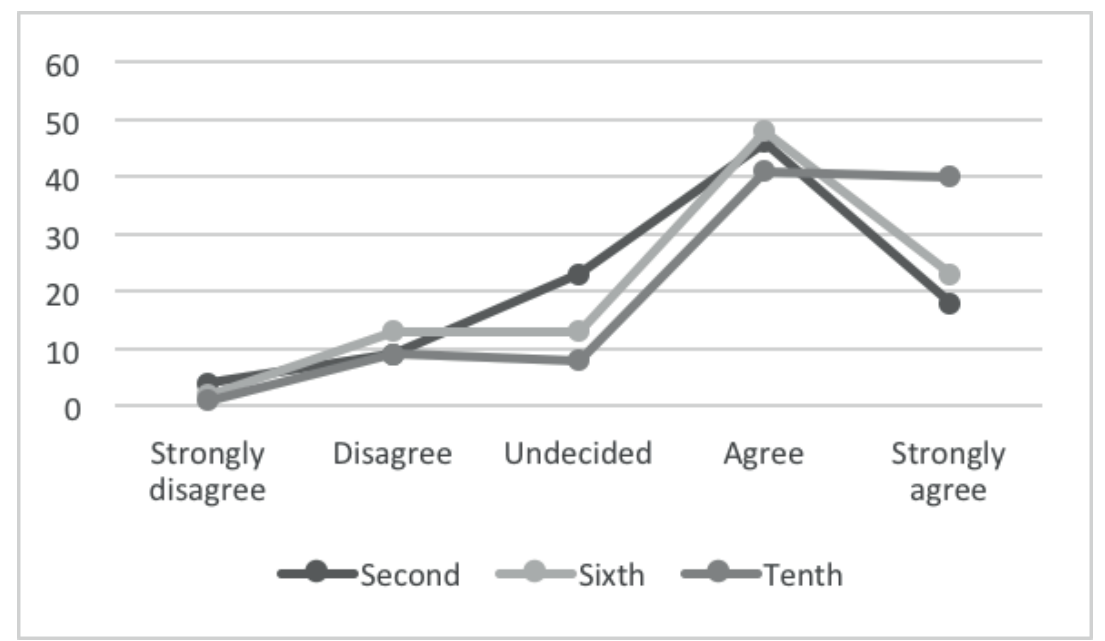

Figure 6. Comparison (in percentages) among the five types of conceptions.

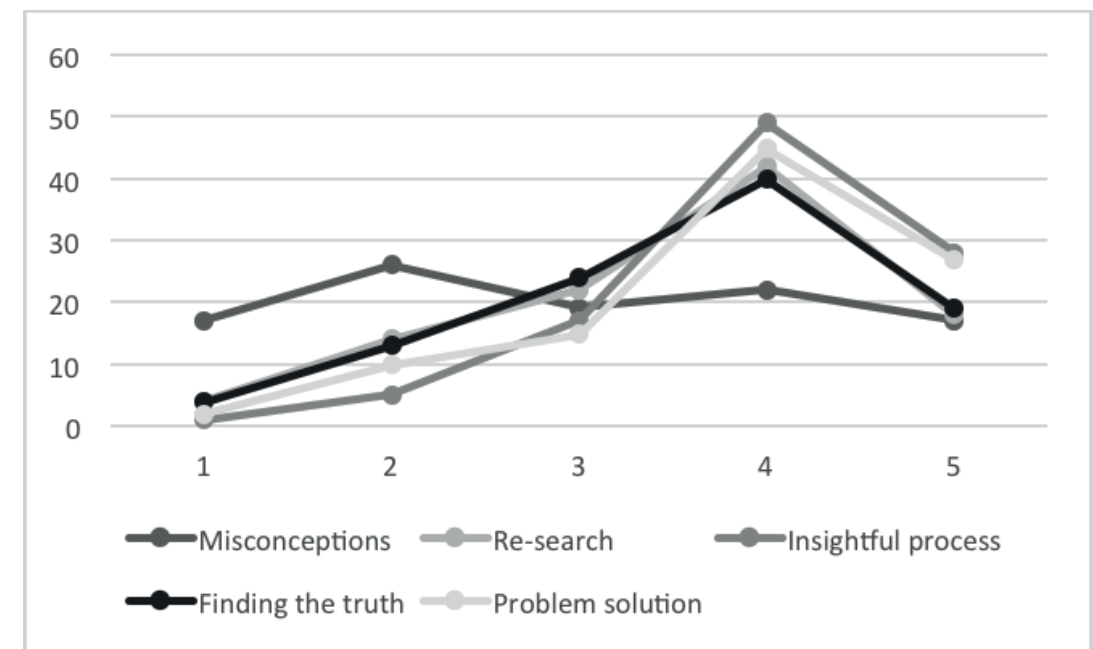


about problem solution" ( $p<0.02)$. This $p$-value is small and therefore significant, "according to the standard values that are commonly used as cut-off points for the significance levels" (Muijs, 2004, p. 78). For more details, see Table 1.

Now we address hypothesis two: there is a difference between age groups and their conceptions of research. In this case cross-tabulations were used. Only the items that showed significance are presented here.

A significant difference was found in the relationship between age and item 5 "Research is about collecting data which back your argument" (chi square $=23.933^{\mathrm{a}}, \mathrm{df}=12, \mathrm{p}=0.021$ ). In this item, undergraduate pre-service EFL teachers from 18 to 20 years and older are more likely to be in agreement than undergraduate pre-service EFL teachers from 21 to 23 and from 24 to 26 years old. The effect size was modest $(\varphi=<0.6)$. For more details, see Table 2 . Item five belongs to misconceptions factor.

Item 17, "research provides a deeper insight and understanding of a particular topic," showed a significant difference (chi square $=25.357^{\mathrm{a}}, d f=12$, $p=0.013$ ). This time, undergraduate pre-service teachers between the ages of 18 and 20 are more likely to be undecided about this item than the rest of the students. The effect size was modest $(<0.6)$. For more details, see Table 3.

Table 1. Fifth Factor and Seniority.

\begin{tabular}{|c|c|c|c|c|}
\hline & & & $\begin{array}{c}\text { Research about problem } \\
\text { solution }\end{array}$ & Semester \\
\hline \multirow{6}{*}{ Spearman's rho } & & Correlation Coefficient & 1.000 & $.225^{*}$ \\
\hline & Research about problem solution & Sig. (2-tailed) & . & .020 \\
\hline & & $\mathrm{N}$ & 107 & 107 \\
\hline & \multirow{3}{*}{ Semester } & Correlation Coefficient & $.225^{*}$ & 1.000 \\
\hline & & Sig. (2-tailed) & .020 & . \\
\hline & & $\mathrm{N}$ & 107 & 108 \\
\hline
\end{tabular}

Table 2. Item 5 and Age

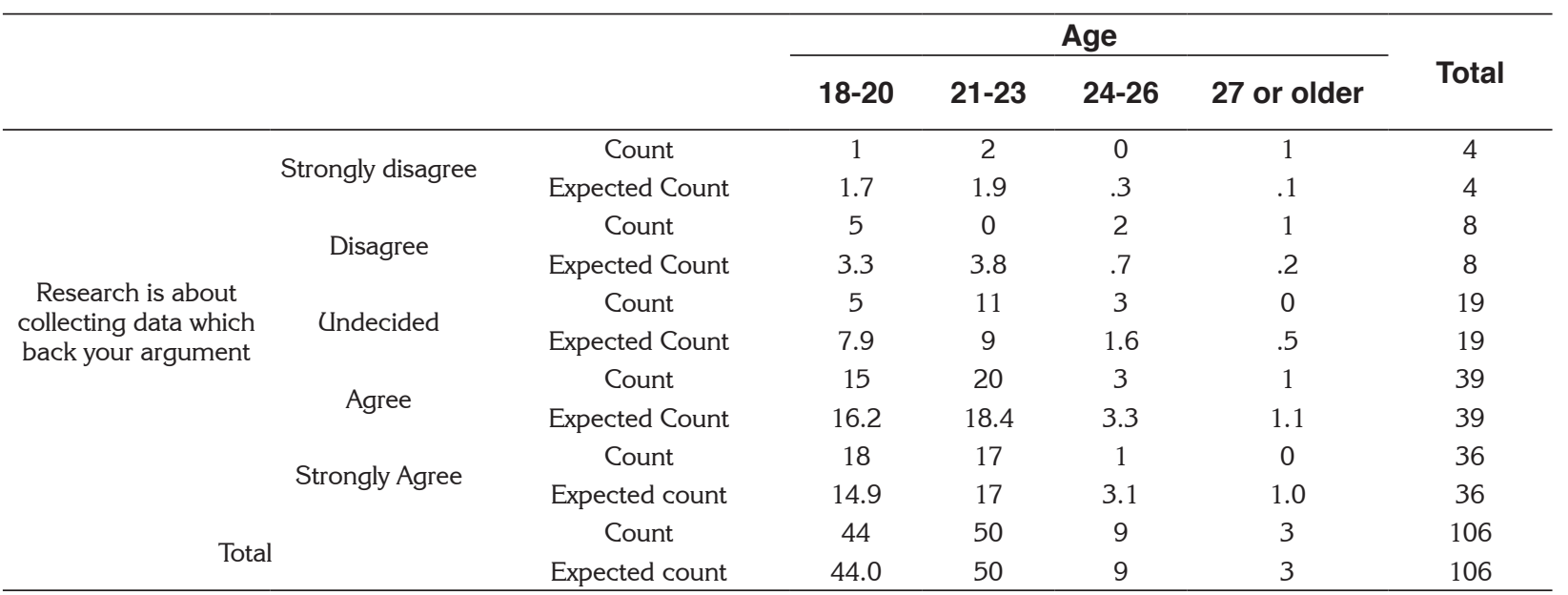


In addition, the study revealed that there is a significant difference in the relationship between age and item 20, "research means searching for more knowledge in a particular field; to accumulate more knowledge" (chi square $=44.454 \mathrm{a}, d f=12$, $p=0.000$ ). Undergraduate pre-service EFL teachers between age 18 and age 20 are more likely to agree with this item than undergraduate pre-service EFL teachers aged 21 to 23 years old and 24 to 26 years old. The effect size was $<0.8$ which is strong according to the measure standards. For more details, see Table 4.
Finally, item 21, "research summarizes existing knowledge (or new knowledge) to create previously unknown insights", yielded a significant difference in relationship with the age variable (chi square $=53.887 \mathrm{a}, d f=12, p=0.000$ ). This time, undergraduate pre-service teachers between ages 21 and 23 years old were the ones who were most likely to agree with this item. The effect size was $<0.8$ which is strong according to the measure standards. For more details, see Table 5.

Table 3. Item 17 and Age

\begin{tabular}{|c|c|c|c|c|c|c|c|}
\hline & & & \multicolumn{4}{|c|}{ Age } & \multirow{2}{*}{ Total } \\
\hline & & & $18-20$ & $21-23$ & 24-26 & 27 or older & \\
\hline \multirow{10}{*}{$\begin{array}{l}\text { Research provides a } \\
\text { deeper insight and } \\
\text { understanding of a } \\
\text { particular topic }\end{array}$} & \multirow{2}{*}{ Strongly disagree } & Count & 0 & 1 & 0 & 1 & 2 \\
\hline & & Expected Count & .8 & 1 & .2 & .1 & 2 \\
\hline & \multirow{2}{*}{ Disagree } & Count & 2 & 4 & 0 & 1 & 7 \\
\hline & & Expected Count & 2.8 & 3.4 & 6 & .2 & 7 \\
\hline & \multirow{2}{*}{ Undecided } & Count & 7 & 5 & 0 & 0 & 12 \\
\hline & & Expected Count & 4.8 & 5.9 & 1.0 & .3 & 12 \\
\hline & \multirow{2}{*}{ Agree } & Count & 21 & 24 & 5 & 1 & 51 \\
\hline & & Expected Count & 20.2 & 25 & 4.3 & 1.4 & 51 \\
\hline & \multirow{2}{*}{ Strongly agree } & Count & 12 & 18 & 4 & 0 & 34 \\
\hline & & Expected Count & 13.5 & 16.7 & 2.9 & 1 & 34 \\
\hline \multirow{2}{*}{ Total } & & Count & 42 & 52 & 9 & 3 & 106 \\
\hline & & Expected Count & 42 & 52 & 9 & 3 & 106 \\
\hline
\end{tabular}

Table 4. Item 20 and Age

\begin{tabular}{|c|c|c|c|c|c|c|c|}
\hline & & & \multicolumn{4}{|c|}{ Age } & \multirow{2}{*}{ Tota } \\
\hline & & & $18-20$ & $21-23$ & 24-26 & 27 or older & \\
\hline \multirow{10}{*}{$\begin{array}{l}\text { Research means } \\
\text { searching for more } \\
\text { knowledge in a } \\
\text { particular field; to } \\
\text { accumulate more } \\
\text { knowledge }\end{array}$} & \multirow{2}{*}{ Strongly disagree } & Count & 0 & 0 & 0 & 1 & 1 \\
\hline & & Expected Count & .4 & .5 & .1 & .0 & 1 \\
\hline & \multirow{2}{*}{ Disagree } & Count & 5 & 1 & 1 & 0 & 7 \\
\hline & & Expected Count & 2.8 & 3.4 & .6 & .2 & 7 \\
\hline & \multirow{2}{*}{ Undecided } & Count & 2 & 7 & 2 & 1 & 12 \\
\hline & & Expected Count & 4.8 & 5.8 & 1 & .3 & 12 \\
\hline & \multirow{2}{*}{ Agree } & Count & 20 & 24 & 3 & 0 & 47 \\
\hline & & Expected Count & 18.9 & 22.8 & 4.0 & 1.3 & 47 \\
\hline & \multirow{2}{*}{ Strongly agree } & Count & 16 & 20 & 3 & 1 & 40 \\
\hline & & Expected Count & 16.1 & 19.4 & 3.4 & 1.1 & 40 \\
\hline \multirow{2}{*}{\multicolumn{2}{|c|}{ Total }} & Count & 43 & 52 & 9 & 3 & 107 \\
\hline & & Expected Count & 43 & 52. & 9 & 3 & 107 \\
\hline
\end{tabular}


Table 5. Item 21 and Age

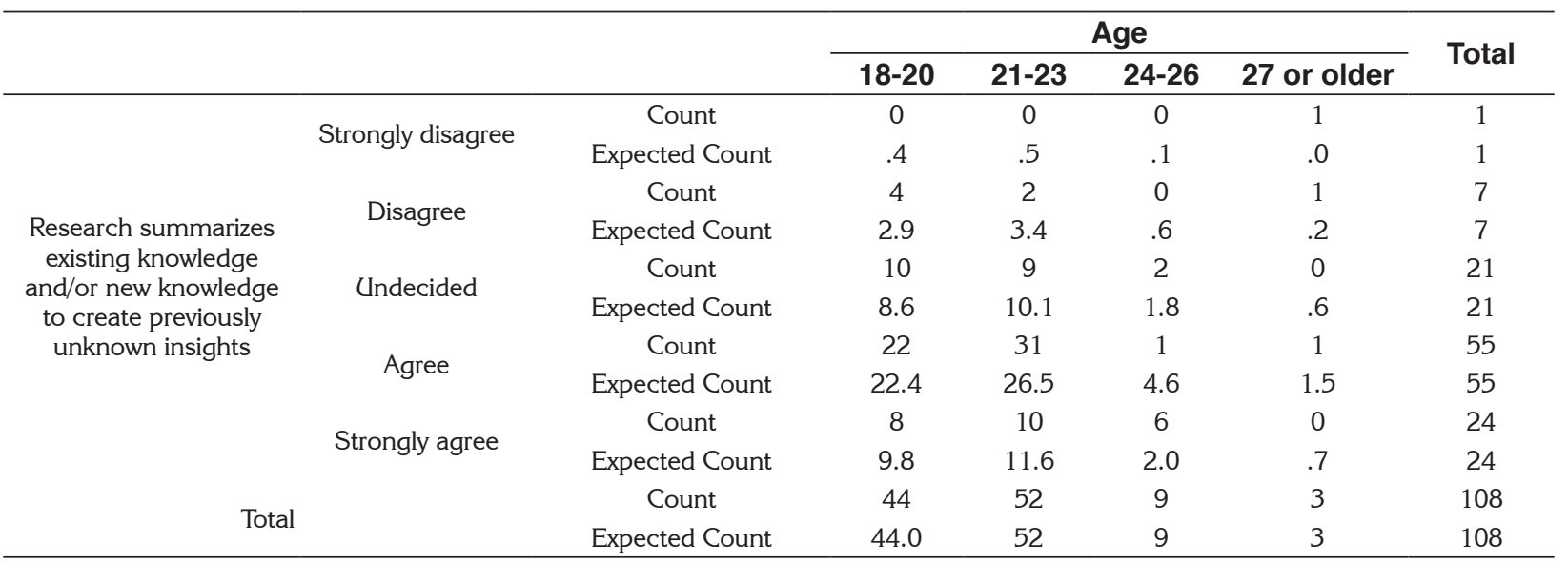

\section{Discussion}

The aim of this study was to explore undergraduate pre-service EFL teachers' research conceptions at Southeastern University. Furthermore, this study aimed at identifying differences and correlation between age, seniority and conceptions of research.

Four out of five types of conceptions of research reported similar percentages among undergraduate pre-service EFL teachers. Nevertheless, we did find a slight variation among pre-service EFL teachers from different semesters with regard to the factor "misconceptions." The findings of this study are similar to Meyer et al.'s (2005) in the sense that neither of the studies showed a uniform concept of research. Other results that can be related to these particular findings are the ones reported by Pitcher and Åkerlind (2009) and Pitcher (2011) who also found varying concepts in the analysis of their studies and, as a result, yielded dimensions of variation.

As it was mentioned, the conceptions of research of pre-service EFL teachers from 2nd, 6 th, and 10th semesters showed variation in the factor "misconceptions" whereas in the rest of the factors variation was not so evident. Pre-service EFL teachers from the second and tenth semesters obtained very similar and low percentages regarding misconceptions, while those from the sixth semester had the highest misconceptions percentages. These results seem to be inconsistent with the time that sixth semester students had spent at university. After sixth semester, an increase of students' intellectual development and a decrease of misconceptions would be expected. In this regard, the academic context in which undergraduate pre-service EFL teachers find themselves may help to explain their "misconceptions." One contextual aspect is the curriculum of the English language major which includes only two research courses, one in the first semester and the other one in the tenth semester. There is a long delay between the first course and the second one-four and a half years to be exact. On the other hand, and based on anecdotal evidence in the English language major, there are few teachers who actually include research projects as part of their courses. This leads us to think that undergraduate pre-service EFL teachers do not exercise their research skills on a regular basis; thus, they are more likely to forget what they had already learned in first semester. This might explain why sixth semester undergraduate pre-service EFL teachers have a higher percentage of misconceptions than those from the second semester. It is true that tenth semester pre-service teachers' had the lowest percentages of "misconceptions", and perhaps this is due to the intellectual growth that pre-service EFL teachers experience as they progress to higher levels 
in their majors (Perry, 1968) or to the fact that they have just taken the course seminario de titulación.

In summary, although tenth semester pre-service EFL teachers were the ones who showed the lowest percentage of misconceptions, it is concerning that sixth semester pre-service EFL teachers have more misconceptions than pre-service teachers from second semester. First, it would have been expected that experience in the major would have increased pre-service EFL teachers' knowledge on certain areas such as research. Second, sixth semester pre-service EFL teachers have advanced more than halfway through their program. Therefore, it would be expected that, at this stage in their studies, these pre-service EFL teachers would know quite well that research is a rigorous process that is conducted in pursuit of scientific truth and should not be manipulated.

Another factor to be considered is teachers' influence on students' conceptions of research. As Visser, Van, Van, Verloop and Visser (2009) mention, teachers are role models who have an important influence on students. Reyes-Cruz \& Hernández Méndez, (2014) carried out a study in which professors of the English language major were the participants. They found that the teachers' publications, resulting from research projects, are modest and that just a few of them have published in journals of high academic rigor. One might then suppose that, due to the fact that the majority of the teachers from the English language major department are starting with the rudiments of research, they have not reached so far into the practice of strategies that may encourage students to read academic articles or to undertake research projects.

It might happen too that professors have misconceptions of research (Kiley $\&$ Mullis, 2007), that they do not read research very often (Borg, 2008), or that teachers who teach methodology courses do not have positive attitudes towards research practice (Aldana \& Joya, 2011). With regards to the latter, it is worth noting that the course metodología de la investigación en ciencias sociales y humanidades (research methodology for the social sciences and the humanities) aims at introducing students to a general perspective of research, which means that they do not approach topics related to the teaching discipline. Besides, those who teach this research methodology class are not trained in the EFL area. In contrast, the course seminario de titulación, the research seminar class (in the ninth semester), focuses on topics related to teaching and is always taught by professors whose professional training is in the EFL area. Therefore, all of these might be factors influencing initial undergraduate pre-service EFL teachers' conceptions of research and the way their conceptions evolve. For that reason, it is suggested that future studies take into account the previously mentioned contextual factors in order to offer a deeper explanation of the phenomenon in focus.

Regarding the results from factor two, "research is re-search," it can be said that those findings indicate functional undergraduate pre-service EFL teachers' perceptions of research. Then, from a pragmatist approach of research, it can be stated that these pre-service teachers believe research indeed involves revising the findings of other researchers who have analyzed and interpreted those, and then challenging or using those studies as a background for new research projects.

In regard to factor three, "research is an insightful process," we think that the students' tendency to agree with this conception is appropriate. This is due to the fact that it has been found (although in other fields) that research definitely helps to better understand published studies, to learn how to balance collaborative and individual work, to define an area of interest (Carrero-Martínez, 2011), to communicate in a better effective way, to develop critical thinking skills, and to develop academic writing (Hunter, 2007; Russell, Hancock, E McCullough, 2007).

The results of factor four, "research is finding the truth," may have a double interpretation. Undergraduate pre-service EFL teachers from those three semesters were likely to be in agreement, but a high percentage were undecided, mostly pre-service teachers from the tenth semester. On the one hand, it might be said that considering research as a pursuit of truth is a functional conception only if it is seen as a systematic scientific process to discover what is happening about a certain phenomenon and 
if the conclusions are reached by using procedures that ensure their validity. The latter is the way the authors of the questionnaire define research.

On the other hand, it might be that pre-service teachers were not sure about how to answer the items of that particular factor; they might have thought that the pursuit of truth means there is indeed only one truth and not several ways to interpret research findings. All of this might indicate the need to develop an epistemological approach which would tend to be sophisticated in terms of Schommer's (1994) considerations. Schommer states that students' conceptions evolve from naïve (usually in the first semesters) to sophisticated (advanced semesters). For this reason, the tenth semester pre-service EFL teachers' indecision might be considered as the demonstration of an evolution of their conceptions to higher levels of complexity. Thus, given the fact that the item "research is finding the truth" may give rise to several interpretations, it would be advisable to revise it in order to remove any confusions that it might cause in future research.

Finally, the results of factor five, "research about problem solution," might be considered as an appropriate conception from a pragmatist viewpoint. From this view, research aims at attaining the necessary understanding to solve human problems as they emerge (Powell, 2001). Perhaps as a result of the nature of the English teaching field, these undergraduate pre-service EFL teachers associate research with solving classroom problems. Therefore, this kind of conceptions might help improve their teaching practice although it should not be forgotten that basic research is also important to generate new knowledge.

In relation to the first hypothesis, "there is a correlation between seniority and conceptions of research," the factor "research is about problem solution" was the only one that showed a significant but weak correlation with the seniority variable. A possible explanation for this finding is that the basic objective of higher education at the undergraduate level is not focused on training researchers. Nevertheless, it is necessary to promote positive attitudes among future professionals toward research so that they can envisage research practice in their professional training as a tool to face teaching problems (Aldana E Joya, 2011).

In the case of the English language program, its aim is to train teachers; this makes us infer that, due to its professional orientation, pre-service EFL teachers from tenth semester tend to associate research practice to the solution of problems related to the English teaching process. Courses such as práctica docente I and práctica docente II, with the latter being the current course taken during the time of this research, may influence pre-service EFL teachers to build up a connection between these two areas.

The absence of a correlation in the majority of the factors between seniority (semester level) and the undergraduate pre-service EFL teachers' conceptions of research was not expected. The explanation could be what Ruiz and Torres (cited in Aldana \& Joya, 2011) have found: certain research classes do not contribute to training students in this area successfully. Furthermore, Allison and Carey (2007) found that people studying at different levels with different educational backgrounds had trouble managing primary research. They also suggested that lack of confidence was an influencing factor. Alison and Carey's findings are similar to our results in the sense that educational background does not mean that students or novice teachers will have a better engagement with research and perhaps, in this case, a better conceptualization of research.

Regarding our second hypothesis, findings allowed us to determine that there are differences between age range and conceptions of research, even though there were only four items which showed a variation. One item belongs to the first factor, "misconceptions," while the other three correspond to the third factor, "research is an insightful process." These results may not be compared to previous studies since we did not find any research dealing with students' conceptions that has taken into account age as a variable. Therefore, there were no other results we may compare ours to. However, differences did appear in those four items, which means that there is a slight difference between age and the pre-service EFL teachers' conceptions of research. 
Although these findings cannot be supported by previous ones, the difference found between item 5 (Research is about collecting data which back your argument) and age (range 18 to 20 years) could be related to the fact that students enter college with already established conceptions that are usually built at home and school. These conceptions are usually reinforced by data from books where knowledge is seen as something fixed and given by an authority. At Southeastern University, courses (at least in the above mentioned major) seem to be based on books and a few on research articles which actually are more likely to show the tentative character of knowledge. Therefore, the previous concepts of pre-service teachers and the lack of opportunity they have to read research articles might be factors that inhibit the development of more sophisticated research conceptions no matter these pre-service teachers' age nor time spent at college. A similar situation was reported by White (2000) and De Juanas, Navarro, and González-Olivares (2011) but in a research study related to epistemological beliefs, age, and gender. Here, it is of paramount importance to state that this study sees research from a pragmatist point of view, which allows the use of different theoretical frameworks and a variety of methods with the objective of finding a solution to the problem being stated.

Regarding the differences found in items 17 (research provides a deeper insight and understanding of a particular topic) and 20 (research means searching for more knowledge in a particular field; to accumulate more knowledge), younger students (aged 18-20) tend to be hesitant. The explanation for this may be related to the fact that most of these students were just beginning their university studies. In Mexico, the low of quality of high school education is well known (Legorreta, 2009) as well as the lack of relation between content and skills developed at this level and the ones needed at the university (Almazán, 2001). Therefore, it may be stated that these students have not been trained to do more complex ranges of tasks nor use research as a learning tool. The difference within this age group (18 to 20) coincides with one found in item five in relation to the same age group; these findings then show that the very same students have a tendency to see research as a way to find evidence to support their position.
Regarding the difference found in item 21 (research summarizes existing knowledge-or new knowledge-to create previously unknown insights), students from 21 to 23 years of age are more inclined to agree with this statement than students from the other age groups. This may be because most of these students are from ninth semester and have just taken the course seminario de titulación (research seminar), thus they have just recently learned that research means to review previous findings so as to propose new explanations for it. Likewise, the difference may have been caused by students' intellectual growth. In this, this finding is in line with Schommer (1993) who found out that students from advanced semesters were less inclined to believe that knowledge is always truth and definitive. Similarly, Hofer and Pintrich (1997) and Hofer (2001) pointed out that there is a tendency to develop sophisticated concepts as they advance in age and, in particular, have new learning experiences. Nevertheless, it is necessary to emphasize that this tendency was only found in item 21 , this is then an opportunity to further research projects that may allow a more detailed explanation about this topic.

\section{Conclusion}

The principal aim of this study was to explore the conceptions or misconceptions of research pre-service EFL teachers of the 2nd, 6th, and 10th semester of the English language program at Southeastern University hold, and to analyze whether variables such as the semester and age were related to such conceptions. That aim was achieved by analyzing the responses from a paper and pencil survey completed by three groups of undergraduate pre-service teachers. This study adds to the scarce literature on students' conceptions of research and, in particular, the conceptions of research held by undergraduate, pre-service EFL teachers.

With regard to the dominant conceptions undergraduate pre-service EFL teachers have towards research, it was found that in three of the five factors analyzed (research is re-search, research about problem solution, research is an insightful process) there was no significant difference on the 
percentages reached by pre-service EFL teachers from the three semesters studied. The previous conceptions are considered as functional. There were moderate differences in the factor "research is finding the truth." In this case, pre-service EFL teachers from the tenth semester tended to be more hesitant than pre-service EFL teachers from the sixth or the second semester. The findings might indicate functional as well as non-functional conceptions depending on students' interpretation of the same item. Participants may have interpreted that research means finding a unique truth or that by following a systematic method one might find one of the possible truths. The different interpretations of the items may imply that the item's wording needs to be improved. The most significant difference was found in the factor "misconceptions" where tenth semester pre-service EFL teachers achieved the lowest percentages, followed by those from the second semester. Surprisingly, pre-service EFL teachers from the sixth semester got the highest percentages. Nevertheless, it was also found that the factor "misconceptions" got the lowest percentage of all of the factors. In other words, it is true that pre-service EFL teachers have conceptions that might be considered as inadequate; nonetheless, misconceptions are much less prevalent than functional conceptions. Undoubtedly, it is necessary to implement measures which contribute to address or correct the misconceptions.

Concerning our first hypothesis, some differences were found only between semester (seniority) and factor 5 "research is about problem solution." This finding could be due to the applied nature of the discipline. With respect to the second hypothesis, some differences were found in one of the items from the factor "misconceptions" and in three more from the factor "research is an insightful process." There appear to be few significant correlations between undergraduate pre-service EFL teachers' research conceptions and seniority. Similarly, the differences between the research conceptions and age groups were scarce. Nevertheless, the fact that the effect size was moderate in two of the items and strong in two others deserves further exploration.

Findings that have been discussed in this present paper pertain to an early stage of analysis. It is worth noting that we will continue investigating this topic for at least some years, so the possibility of revision is considered. These findings offer useful insights and ideas that might be used as a foundation for further studies in the EFL field, especially in Mexico. We suggest that a better understanding of research conceptions be encouraged, especially among project leaders and instructors since mismatches in conceptions can cause communication issues.

This research study was limited to investigating undergraduate pre-service EFL teachers' research conceptions through a survey. Although data were collected to have an idea of what these concepts mean and how suitable they are, there were limitations that could have affected the results and that should be taken into account in further research. One of them is that we chose to work with a convenience sample; therefore, the results cannot be extrapolated. Another issue is that the questionnaire used was limited to asking about previously established concepts, leaving aside some others the pre-service EFL teachers might have but that we did not explore. Likewise, the lack of literature in the field and the lack of a specific theory to explain the findings limited our interpretation thereof.

Therefore, it is necessary to conduct further work on pre-service EFL teachers' research conceptions so as to reach a better understanding of the topic. It is important to come up with new ideas, new hypotheses, and research questions. The points to work with in future research are as follows:

- Other possible factors that might influence preservice EFL teachers' research conceptions should be analyzed by using other instruments for research.

- This research study should be replicated using a qualitative approach. It would be useful to obtain data by using different research perspectives. Although the survey research gives relevant data, it needs to be complemented by different approaches so the issue could be seen in its all dimensions.

- Professors' and lecturers' conceptions of research should be analyzed since they are an important influence and are also frequently seen as role models by their students. It is important 
to analyze specifically those professors who supervise research projects.

- An important issue to explore is the design of research courses provided by the institution as it might be another factor that influences undergraduate pre-service EFL teachers' conceptions.

\section{References}

Aldana, G., \& Joya, N. (2011). Actitudes hacia la investigación científica en docentes de metodología de la investigación. Tabula Rasa, 14, 295-309.

Allison, D., \& Carey, J. (2007). What do university language teachers say about language teaching research? TESL Canada Journal, 24(2), 61-81.

Almazán, J. L. (2001). La educación media superior en México. Coparmex-Entorno, febrero. Retrieved from: http://www.coparmex.org.mx/contenidos/publicaciones/ Entorno/2001/febrero01/ed_medsup.htm

Atay, D. (2006). Teachers' professional development: Partnerships in research. TESL-EJ, 10(2), 1-14.

Reyes-Cruz, M. R. \& Hernández-Méndez, E. (2014). Productividad y condiciones para la investigación: El caso de los profesores de lenguas extranjeras. Sinéctica, 42, 1-17.

Bell, M., Cordingley, P., Isham, C., \& Davis, R. (2010). Report of professional practitioner use of research review: Practitioner engagement in and/or with research. Retrieved from: http://www.curee.co.uk/ files/publication/[sitetimestamp]/Practitioner\%20 Use\%20 of\%20Research\%20Review\%20-\%20 FINAL\%2011_02_11.pdf

Beycioglu, K., Ozer, N., \& Teyyar, C. U. (2010). Teachers' views on educational research. Teaching and Teacher Education, 26, 1088-1093. doi: 10.1016/j. tate.2009.11.004

Biesta, G. J., E Burbules, N. C. (2004). Pragmatism and educational research. Lanham, MD: Rowman and Littlefield Publishers.

Bills, D. (2004). Supervisors' conceptions of research and the implications for supervisor development. International Journal for Academic Development, 9, 85-97. doi:10.1080/1360144042000296099

Borg, S. (2008). English language teachers' beliefs about research: Perspectives from the Netherlands. Levende Talen, 9(3), 3-13.

Borg, S. (2009). English language teachers' conceptions of research. Applied Linguistics, 30(3), 358-388. doi:10.1093/applin/amp007
Borg, S. (2013). Teacher research in language teaching. London, U.K.: Cambridge University Press.

Brew, A. (2001). Conceptions of research: A phenomenographic study. Studies in Higher Education, 26(3), 271-285.

Carrero-Martinez, F. A. (2011). Rethink summer student research. Science, 334-313.

De Juanas, A., Navarro, E., \& González-Olivares, A. L. (2011). Estudio confirmatorio de la estructura factorial del cuestionario de creencias epistemológicas con una muestra de estudiantes universitarios de la UCM. In J. M. Román, M. A. Carbonero, \& J. Valdivieso, (Eds.), Educación, aprendizaje y desarrollo en una sociedad multicultural (pp. 5692-5700). Madrid: Asociación de Psicología y Educación y Colegio Oficial de Psicólogos de Castilla y León.

DeVellis, R. F. (1991). Scale development: Theory and applications. Applied social research methods series (vol. 26). Newbury Park: Sage.

Edwards, C. (2005). Teachers exploring research. In C. Edwards \& J. Willis. (Eds.), Teachers exploring task in English language teaching (pp.2 56-279). Basingstoke: Palgrave McMillan.

Gao, X., Barkhuizen, G., \& Chow, A. W. K. (2011). "Nowadays teachers are relatively obedient": Understanding primary school English teachers' research experiences in China. Language Teaching Research, 15(1), 61-81.

Golafshani, N. (2003). Understanding reliability and validity in qualitative research. The Qualitative Report, 8(4), 597-606

Halabi, J. O., \& Hamdan-Mansour, A. (2010). Attitudes of Jordanian nursing students towards nursing research. Journal of Research in Nursing, 17(4), 363-373. doi:10.1177/1744987110379782

Hofer, B. K., \& Pintrich, P. R. (1997). The development of epistemological theories: Beliefs about knowledge and knowing and their relation to learning. Review of Educational Research, 67, 88-140. doi:10.3102/00346543067001088

Hofer, B. K. (2001). Personal epistemology research: Implications for learning and teaching. Educational Psychology Review, 13, 353-383. doi:10.1023/A:1011965830686

Hunter, P. (2007). Undergraduate research. Winning the battle for students' hearts and minds, EMBO Rep. 8(8), 717-719. doi: 10.1038/sj.embor.7401039

Kiley, M., \& Mullins, G. (2007). Supervisors' conceptions of research: What are they? Scandinavian Journal of Educational Research, 49(3), 245-262. doi: $10.1080 / 00313830500109550$ 
Lee, A. (2008). How are doctoral students supervised? Concepts of doctoral research supervision. Studies in Higher Education, 33(3), 267-281.

Legorreta, G. (2009). El devenir de la educación media superior. El caso del estado de México, Tiempo de Educar, 10(19), 171-204.

Love, K. M., Bahner, A. D., Jones, L. N., \& Nilsson, J. E. (2007). An investigation of early research experience and research self-efficacy. Professional Psychology: Research and Practice, 38(3), 314-320. doi: 10.1037/0735-7028.38.3.314

Lucas, L., Healey, M., Jenkins, A., \& Short, C. (2008). Academics' experiences and perceptions of 'research' and 'teaching': Developing the relationship between these activities to enhance student learning within different disciplines and institutions. The Higher Education Academy, 8(3), 4-54.

Meyer, J. H. F., Shanahan, M. P., \& Laugksch, R. C. (2005). Students' conceptions of research I: A qualitative and quantitative analysis. Scandinavian Journal of Educational Research, 49, 225-244.

Moore, S. (2011). Cambodian English teachers' conceptions of and engagement with research. Proceedings of the international conference: Doing research in applied linguistics, 83-98. Retrieved from: http://arts.kmutt.ac.th/dral/PDF\%20proceedings\%20 on\%20Web/8398_Cambodian_ English_Teachers Conceptions.pdf

Muijs, D. (2004). Doing quantitative research in education with SPSS. Thousand Oaks, CA: Sage.

Perry, W.G. (1968). Forms of intellectual and ethical development in the college years: A scheme. New York, NY: Rinehart and Winstong.
Pitcher, R., EÅkerlind, G.S. (2009). Postdoctoralresearchers' conceptions of research: A metaphor analysis. The International Journal for Researcher Development, 1, 42-56. doi: 10.1108/1759751X201100009

Pitcher, R. (2011). Doctoral students' conceptions of research. The Qualitative Report, 16(4), 971-983.

Powell, T. (2001). Competitive advantage: Logical and philosophical considerations. Strategic Management Journal, 22, 875-888. doi: 10.1002/smj.173

Ramírez, J. L. (Ed.). (2013). Una década de búsqueda: las investigaciones sobre la enseñanza y el aprendizaje de lenguas extranjeras en México 2000-2011. México: Pearson, UNISON, UNAM, UCOL.

Russell, S. H., Hancock, M. P., \& McCullough, J. (2007). THE PIPELINE: Benefits of undergraduate research experiences. Science, 316,548-549.

Schommer, M. (1993). Epistemological development and academic performance among secondary students. Journal of Educational Psychology, 85(3), 406-411.

Schommer, M. (1994). An emerging conceptualization of epistemological beliefs and their role in learning. In R. Gardner \& P. A. Alexander (Eds.), Beliefs about text and instruction with text (pp. 25-40). Hillsdale, NJ: Lawrence Erlbaum Associates.

Visser, G. J.,Van, J. H, Van, R. M.,Verloop, N., E Visser A. (2009). The relationship between academics' conceptions of knowledge, research, and teaching - a metaphor study. Teaching in Higher Education, 14, 673-686.

White, B. C. (2000). Pre-service teachers' epistemology viewed through perspectives on problematic classroom situations. Journal of Education for Teaching, 26(3), 279-305. 